\title{
ESTUDO DE MOLHABILIDADE SUPERFICIAL DO NITRETO DE BORO HEXAGONAL (H-BN) NA BRASAGEM À VÁCUO*
}

\section{Resumo}

Marcio José Cuccolo Rosales ${ }^{1}$ Conrado Ramos Moreira Afonso ${ }^{2}$

A soldagem por brasagem a vácuo promove a união de materiais dissimilares com alto valor agregado. Este trabalho visa estudar a interação química do nitreto de boro hexagonal (h-BN) na interface de ligação brasada do par Kovar®/h-BN. As variáveis de processo são determinantes para formação da junta brasada metalurgicamente estável. $\mathrm{O}$ trabalho estuda a molhabilidade do $\mathrm{h}$-BN quando em contato com ligas de adição do sistema eutético $\mathrm{Ag}-\mathrm{Cu}$ durante a solidificação. Foram conduzidos ensaios no h-BN a fim de caracterizar sua aplicação no sensor de posição do feixe de elétrons (BPM) do projeto do Sirius, e as propriedades que influenciam o seu processamento durante a brasagem, como coeficiente de expansão térmica e molhabilidade superficial. Os ensaios de brasagem com a liga Ag-Cu-4,5Ti, mostraram boa molhabilidade e espalhamento na superfície, favorecendo a formação da junta sem descontinuidades. As reações na interface são complexas no sentido de formação de novas fases e intermetálicos e, influenciadas pela seleção dos materiais, que possuem diferentes temperaturas de fusão e coeficientes de expansão térmica. Os resultados indicam que a seleção da liga com Ti, que é o elemento de ativação, promove a interação na superfície do hBN com os demais materiais da junta.

Palavras-chave: Brasagem; Nitreto de Boro Hexagonal; Molhabilidade; Projeto Sirius.

\section{SURFACE WEATTABILITY OF HEXAGONAL BORON NITRIDE (H-BN) IN VACUUM BRAZING PROCESS}

\section{Abstract}

The vacuum brazing promotes the bonding of dissimilar materials with high technological value process. This work aims to study the chemical interaction of hexagonal boron nitride (h-BN) at Kovar® / h-BN pair brazed interface. The process variables play an important role for the formation of metallurgically stable brazed joint. It was studied the h-BN wettability when in contact with eutectic Ag-Cu filler metal during solidification. Testes were carried out to characterize its application as solid solution to bond the components of the beam position monitor (BPM) designed to Sirius project. The h-BN properties that influence processing conditions, such as thermal expansion coefficient and surface wettability were investigated. The brazing tests with the Ag-Cu-4.5Ti filler showed good wettability and surface scattering, favoring the formation of defect free brazed joint. The reactions at the interface are complex in the sense of new phases and intermetallic formation. They are influenced by the selection of materials that have different physical properties. The results indicate that the selection of $\mathrm{Ti}$ content alloy, which is the activation element, promotes the interaction on the h-BN surface with other base materials of the joint.

Keywords: Brazing; Hexagonal Boron Nitride; Wettability; Sirius Project.

1 Engenheiro de Materiais/UFSCar, Doutorando, Pesquisador/Sócio, Departamento de P\&D, Brazitec Tecnologia em Materiais/UFSCar, Campinas, São Paulo, Brasil.

2 Engenheiro de Materiais/UFSCar, Doutor, Professor Adjunto, Departamento de Engenharia de Materiais, UFSCar, São Carlos, São Paulo, Brasil. 


\section{INTRODUCTION}

Many components developed to synchrotron light source machine are manufactured by brazing process in high vacuum environment, which promotes the formation of dissimilar joints, compatible for this application. The process of bonding these materials using conventional welding processes is not possible due to their inherent characteristics, such as distortion generated by high temperature gradient, presence of cracks caused by difference in thermal expansion coefficients of materials, possibility of pores and inclusions formation, which would limit the use of these components when applied in ultra-high vacuum environment.

The construction of the new Brazilian light source machine (Sirius project) is associated with the application of new advanced materials, since its conceptual design reaches the state of the art in several areas of knowledge. Therefore, the development of the beam position monitor (BPM) is directly related to the surface wettability study of h-BN, used as an electrical insulator. The challenge of this work is to study the vacuum brazing to characterize the formation of metal-ceramic bonding interface to meet the constructive demands of BPM, using h-BN, which has low surface wettability when in contact with filler metal. Although, no precedents were found in literature review about the process of joining this material, which characterizes the great challenge of this project. The h-BN does not show wettability with most of the molten metal alloys when in contact with its surface [1-5].

Vacuum brazing promotes the formation of joints with high mechanical strength, in addition to the application in ultra-high vacuum, an essential feature for use in the synchrotron light ring. The filler when in the liquid state wet the contact surfaces of the materials, favoring the formation of reactions with strong metallurgical interaction. The process is used in situations in which complex geometries are essential design requirements, and is indicated for joining dissimilar materials, which have different physical properties, such as melting temperature, thermal expansion coefficient and conductivity. Furthermore, the process temperature is lower than the melting temperature of base materials, which leads to less energy input and low residual stresses at the bonding interface $[3,4]$.

The wettability of a solid by a liquid is the variable that is related to the surface interaction between the materials during brazing, and depends on the magnitude of interfacial energies [6-7]. The phenomenon is described by wetting angle, which varies as function of free energy of the interfaces under equilibrium conditions. Systems in which liquid-solid interaction occurs promote the formation of new compounds, due to phenomena such as diffusion, precipitation and segregation of phases and constituents. The physical and kinetic study of reactive wettability are quite complex, since the behavior of the interaction is due to the concentration of active elements, i.e. $\mathrm{Ti}$ or $\mathrm{Zr}$ [8]. The interfacial reactions and scattering must consider nucleation and growth phenomena, evaporation-condensation of reactive elements, chemical reactions in solidification and coalescence of the reaction products at the solid-liquid interface [11-13]

The solid-state reactions during brazing are combined with chemical diffusion of filler elements in the liquid state, changing the materials properties at the interface region. For the process to occur it is essential that both filler alloy and base materials have chemical affinity to ensure solubility or precipitation of the elements in the crystalline lattice. So, the diffusion stems from brazing temperature and time at the process stage. 
When welding dissimilar materials, the percentage of the active metal present in the filler alloy determines the characteristics of the interface formation. If on the one hand the lack of active element causes non-wetting of the surface on the ceramic material, on the other hand, excess amounts can lead to the increase of fragility by the formation of complex intermetallic compounds [14]. Thus, the proper selection of filler alloy plays an important role to guarantee the quality of brazing joint and must consider factors such as the chemical composition of the base materials and the properties of the filler when in liquid state and after solidification and cooling.

The $\mathrm{Ti}$ and $\mathrm{Zr}$ elements are the most widely used to induce interface reactions, although others such as $\mathrm{Ta}, \mathrm{Nb}, \mathrm{Al}, \mathrm{Cr}$ and $\mathrm{V}$ produce similar effects [9-12]. Ti is the most used element, since its addition substantially favors wetting and scattering by reducing the contact angle and increasing adhesion forces. The higher the concentration of the reactive elements in the alloy, the lower the wetting angle $[8,17]$. The thermodynamic activity of $\mathrm{Ti}$ makes it rapidly segregated to the interface, reacting with the other elements of the base materials, to form new compounds.

\section{MATERIALS AND METHODOLOGY}

The work was conducted with wettability tests to determine interfacial boundary characteristics of h-BN when brazed in vacuum atmosphere to form metal-ceramic brazed pair. The process variables were evaluated to guarantee the necessary conditions for the BPM construction, following design requirements defined by the National Synchrotron Light Source (NSLS) laboratory. There were realized tests to characterize the h-BN raw material in terms of microstructure and physical properties that could influence the component's characteristics during brazing, such as thermal expansion coefficient at the brazing temperature $\left(850^{\circ} \mathrm{C}\right)$.

The ceramic base material selected was Mycrosint $\mathrm{HD} B$. This material is processed by HIP (Hot Isostatic Pressure) which promotes isotropic properties. The selection of the filler was determined considering the chemical composition of base materials (Fe$\mathrm{Ni}$-Co alloy Kovar®) and h-BN itself. The kinetics of the interface formation depends on chemical elements present in the filler alloy. In this way, it was tested $78 \mathrm{Ag}-22 \mathrm{Cu}$ (Cusil囚) and $\mathrm{Ag}-\mathrm{Cu}-4.5 \mathrm{Ti}$ (Ticusil囚) eutectic alloys, in which $\mathrm{Ti}$ acts as surface activation element to guarantee the bonding interface with $\mathrm{h}-\mathrm{BN}$.

The surface wettability tests of $\mathrm{h}$-BN when in contact with molten alloy using both eutectic fillers were conducted at the Foundry Research Institute of Poland. The tests were performed by a sessile drop method at the temperature of $\mathrm{T}=865^{\circ} \mathrm{C}$ under vacuum in experimental procedures of contact heating and capillary purification. The objective was to measure the contact angle of the metal liquid drop with the ceramic substrate. The results were conducted in comparative with the usual $\mathrm{Al}_{2} \mathrm{O}_{3}$ substrate. Also, preliminary ceramic-metal brazed pair samples were produced in high vacuum atmosphere $\left(10^{-6} \mathrm{mbar}\right)$ and high temperature $\left(850^{\circ} \mathrm{C}\right)$ to determine the bonding interface of base materials with the selected filler (Ticusil囚), especially to visualize the interaction of $\mathrm{h}-\mathrm{BN}$ at the bonded interface. The variables were selected according to the literature and previous experiments. The tests were conducted at temperature range of $850{ }^{\circ} \mathrm{C}$ soak during $5 \mathrm{~min}$. with heating and cooling rates controlled $\left(5^{\circ} \mathrm{C} / \mathrm{min}\right)$ and using $\operatorname{Kovar}{ }^{\circledR}$ and $\mathrm{h}-\mathrm{BN}$ base materials.

The microstructure evaluation of the h-BN / Ticusil ${ }^{\circledR}$ / Kovar® brazed interface was carried out by optical microscopy image analysis, scanning electron microscopy (SEM) and energy-dispersive spectroscopy (EDS) for the semi-quantitative analysis of composition maps at brazed interface. It was analyzed maps of brazed interface 
composition using Jeol JSM 5900LV equipment at National Laboratory of Nanotechnology (NLNano).

\section{RESULTS}

The microstructural characterization of h-BN (Mycrosint HD) was conducted on the fractured transverse surface. Figure 1 shows no porosity in the analyzed scale order. It shows that the material was formed by the hot isostatic pressing process (HIP), which promotes the formation of a monolithic body with isotropic properties. The result corroborates the use of this ceramic as an electrical insulator for the BPM, especially because this is the main property required for this application.
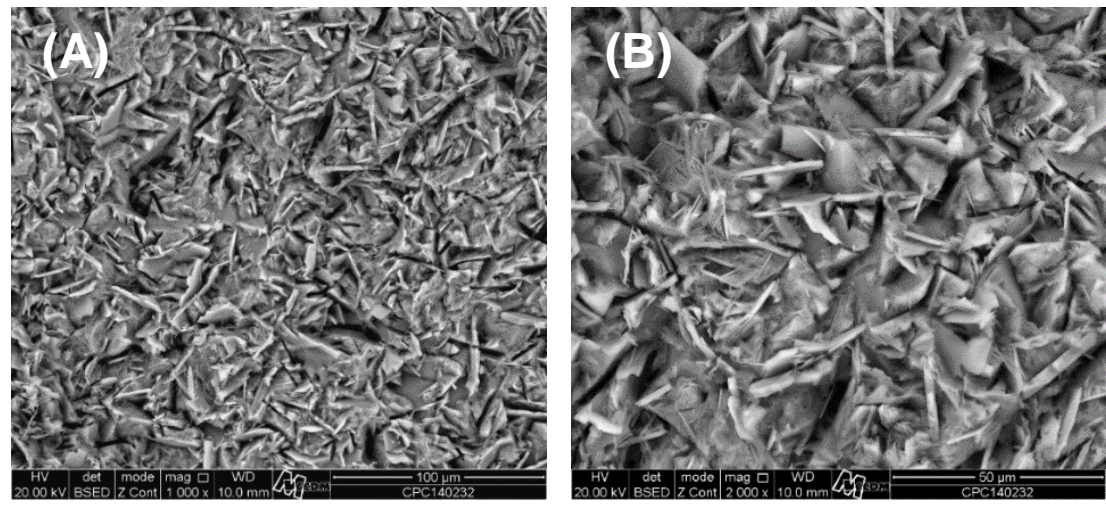

Figure 1. Images of fractured transverse sample of h-BN A) 1000x e B) 2000x.

The linear behavior of the material when subjected to heating cycle in ambient atmosphere - once the material is inert in an oxidizing atmosphere up to $1000{ }^{\circ} \mathrm{C}$ determined the thermal expansion constant $\alpha=-7.810^{-6} \mathrm{~K}^{-1}$ (Figure 2).

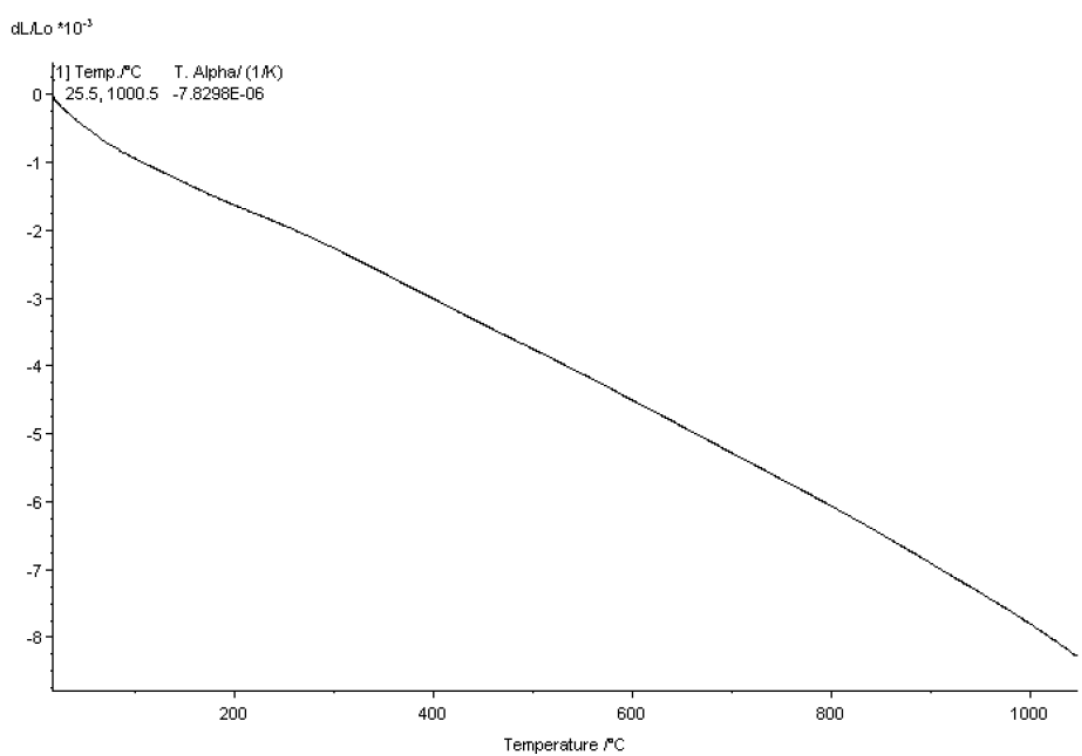

Figure 2. Linear deformation versus temperature for h-BN ceramic.

The negative behavior of thermal expansion coefficient is associated with the crystallographic orientation of the material (hexagonal structure), so that the variation of the expansion with grain orientation tends to decrease with increasing temperature. This is due to the strong anisometric structure of the ceramic material [16]. The main problem observed is because of the mismatch of thermal expansion 
coefficient of dissimilar joint (metal-ceramic brazed pair). So that the use of Kovar®, which has low thermal expansion coefficient is indicated to mitigate possible crack and failure when cooling from high temperature.

The preliminary test of ceramic wettability was produced in high vacuum atmosphere and process temperature of $850^{\circ} \mathrm{C}$. Figure 3 shows the comparison between the two solidified fillers selected using h-BN substrate, containing: (A) $78 \mathrm{Ag}-22 \mathrm{Cu}$ and (B) $\mathrm{AgCu}-4.5 \mathrm{Ti}$. It is possible to see that the alloy (B) dampens the surface of the $\mathrm{h}-\mathrm{BN}$ material completely, while the alloy $(A)$ does not react with the ceramic substrate, promoting the formation of a drop in the surface. The $4.5 \%-\mathrm{Ti}$ element present in Ticusil@ filler promotes its interaction with h-BN surface, which has a natural nonwettability characteristic. The reaction layer is formed by chemical diffusion and metallurgical interaction of these materials due to the affinity of Ti element that acts as main interface activator to form intermetallics and the bonding interface.

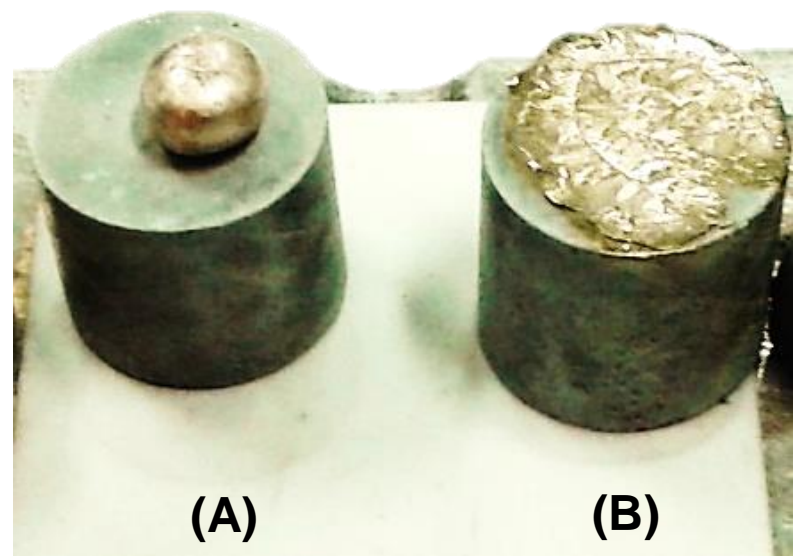

Figure 3. Superficial wettability of $h-B N$ with A) $72 \mathrm{Ag}-28 \mathrm{Cu}$ and B) AgCu-4.5Ti solidified fillers.

The wettability test on h-BN surface when in contact with filler alloy was performed in comparison with $\mathrm{Al}_{2} \mathrm{O}_{3}$ substrate. The $72 \mathrm{Ag}-28 \mathrm{Cu}$ alloy did not wet the surfaces of both ceramic substrates $\left(\theta>>90^{\circ}\right)$. The results indicated good surface wettability of the $\mathrm{Ag}-\mathrm{Cu}-4.5 \mathrm{Ti}$ alloy in contact with both substrates $\mathrm{Al}_{2} \mathrm{O}_{3}\left(\theta_{\text {mean }} \sim 30^{\circ}\right)$ and $\mathrm{h}-\mathrm{BN}$ $\left(\theta_{\text {mean }} \sim 40^{\circ}\right)$. Although the average angle for $\mathrm{h}-\mathrm{BN}$ is higher, this effect (good wettability in the semi-liquid state) favors the reduction of brazing temperature, which may induce a lower residual stress due to the solidification process. Figure 4 shows non-wetting of the surface with $72 \mathrm{Ag}-28 \mathrm{Cu}$. As surface tensions are not measurable, wettability in non-reactive systems can be measured by the contact angle with the sessile drop methodology. However, the results obtained can be used in terms of comparison with the $\mathrm{Al}_{2} \mathrm{O}_{3}$.
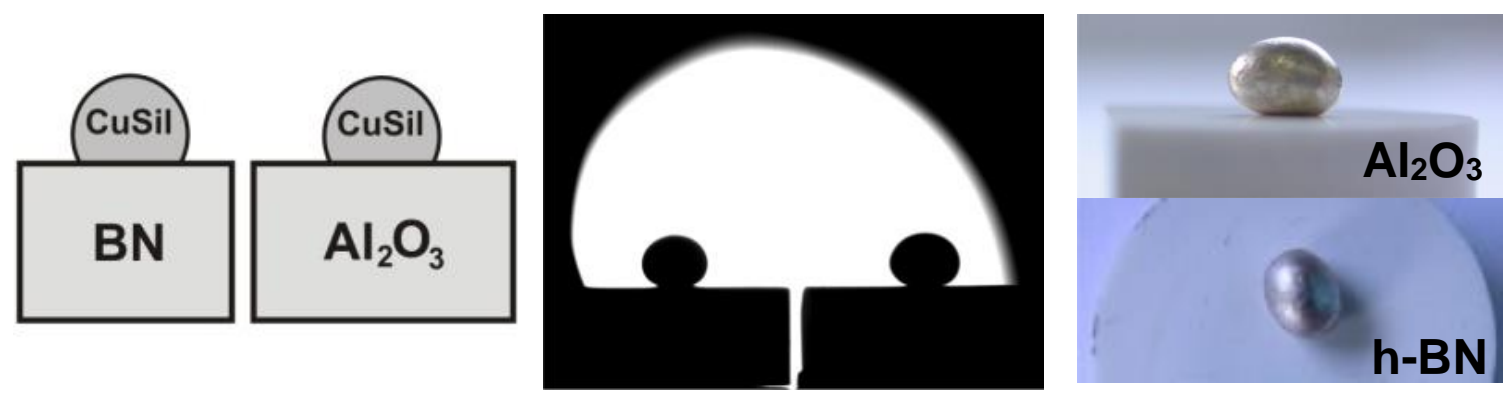
Figura 4. Non-surface wettability condition of h-BN with $72 \mathrm{Ag}-28 \mathrm{Cu}$.

Figure 5 shows the metal in the liquid state under high temperature vacuum $(A)$ and after cooling (B). Ticusil alloy was not completely melted during sessile drop wettability tests. This observation is in agreement with literature data showing that Ticusil $\circledast$ alloy has Tsolidus $=1053 \mathrm{~K}\left(780^{\circ} \mathrm{C}\right)$ and Tliquidus $=1173 \mathrm{~K}\left(900^{\circ} \mathrm{C}\right)$ that is 35 ${ }^{\circ} \mathrm{C}$ above the testing temperature of $865{ }^{\circ} \mathrm{C}$ defined. Brazing that mimics real conditions during brazing also shows a good agreement with the results of the above wettability tests, i.e. even thoughTicusilß is not completely melted at the selected test temperature the liquid already formed at that temperature exhibits good wetting and spreading while its amount is sufficient to fill the gap between two BN substrates. Visual observation of BN/Ticusil/BN joint looks good and free of discontinuities.
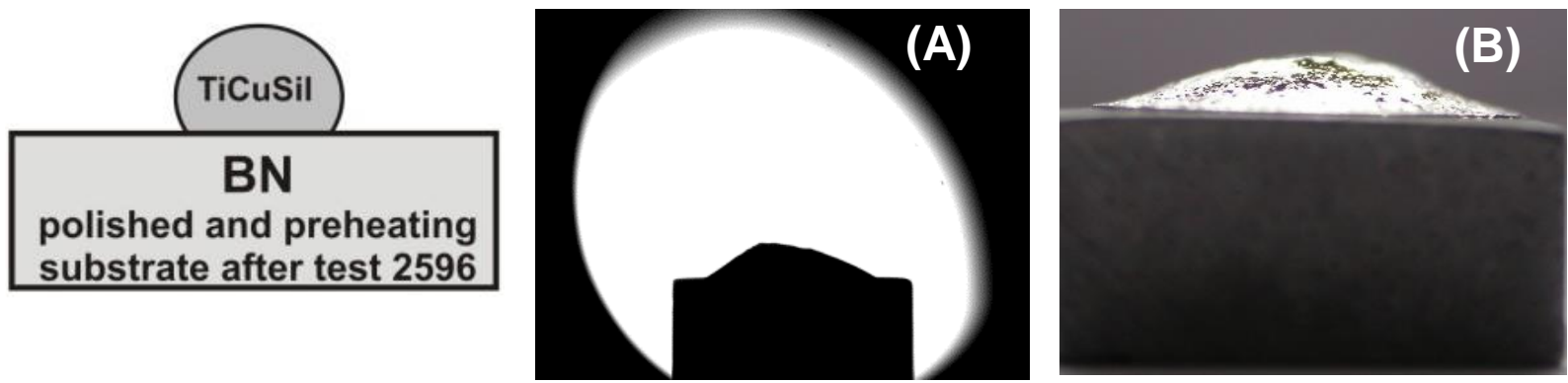

Figura 5. Surface wettability of h-BN with AgCu-4.5Ti.

Figure 6 shows the scanning electron microscopy mapping (EDS), in which it is possible to identify the main elements present in Ticusil ${ }^{\circ}$ filler alloy, including the $\mathrm{Ti}$ element, at the interface region between $\mathrm{Al}-\mathrm{Cu}-\mathrm{Ti}$ alloy and $\mathrm{h}-\mathrm{BN}$, whereas the other chemical elements of the composition remain diffuse in the eutectic $(\mathrm{Ag}-\mathrm{Cu})$, light gray. The arrow indicates this interface region between both materials. It is possible to observe that the interaction layer is straight, approximately with $50 \mu \mathrm{m}$ thickness. Also, it is important to notice that the thickness of the bonded region is result of diffusion reaction of these materials at the interface. It can influence the mechanical proprieties behavior of the brazed joint. The literature indicates that the higher the interface reaction layer, the lower the joint resistance [18]. The diffusion is thermal activated process which means it depends exponentially on time and temperature parameters.

The results indicate the selection of $\mathrm{AgCu}-4,5 \mathrm{Ti}$ to guarantee the formation of the interface between $\mathrm{h}-\mathrm{BN}$ and the other metal alloys (including the filler itself and Kovar® alloy) involved in the process. To evaluate the chemical interaction on the surface, the EDS mapping at the interface shows the Ti element migration to regions close to the ceramic substrate - indicating the occurrence of diffusion in the bonding region.

Further, the chemical composition of the alloy minimizes the separation effect of the joint to become compatible with the substrate materials. It is worth mentioning that the formation of the intermetallics, resulting from the chemical reactions of the filler and the substrate, was not complete investigated at this stage, since the objective was determined to study the initial feasibility of using the vacuum brazing process in the formation of the $\mathrm{h}-\mathrm{BN}$ bonding interface to produce the metal-ceramic pair. 

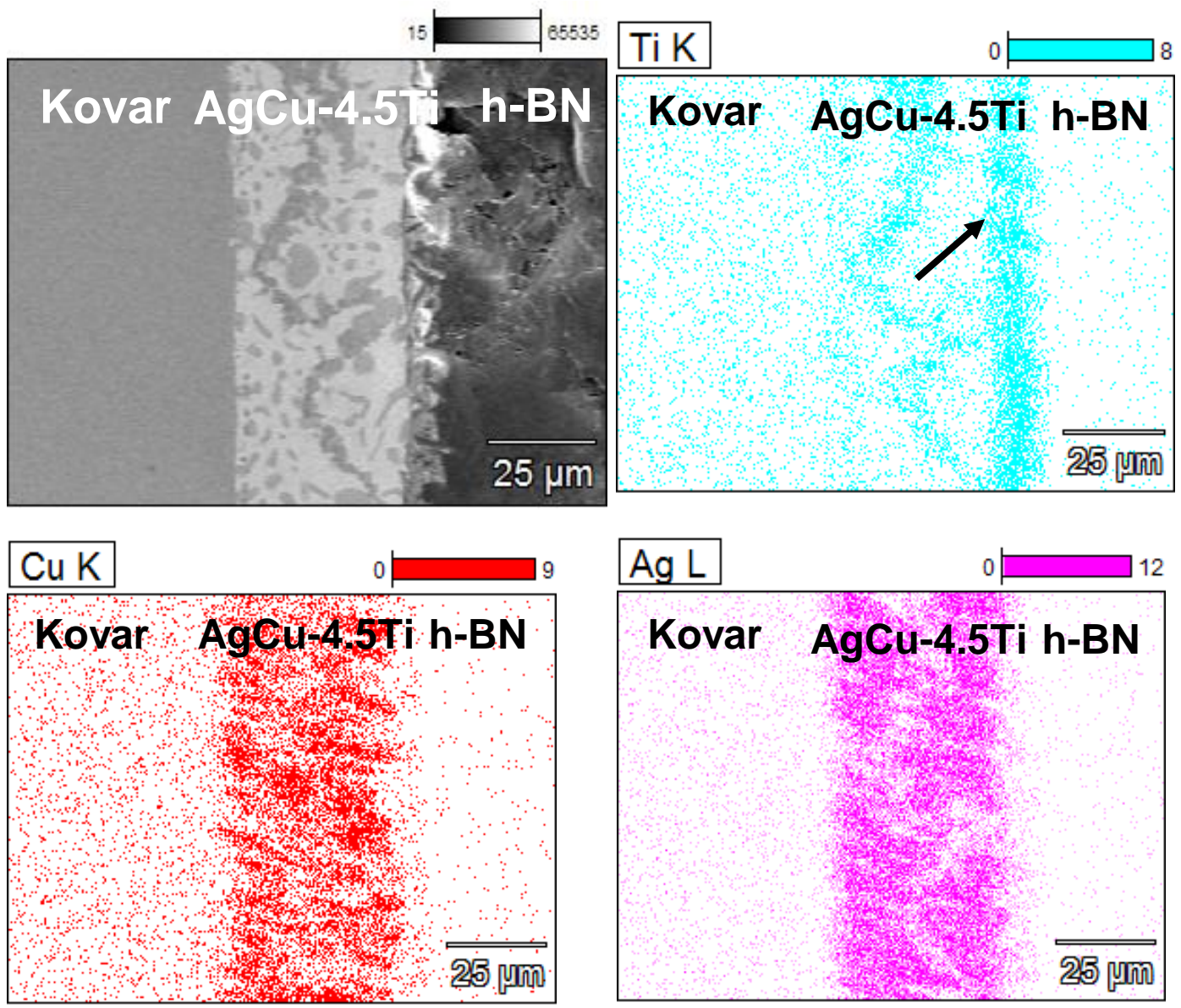

Figure 6. SEM micrograph in (a) BSE signal substrate of Mo metal side (left), intermixing region mainly on the right side between $\mathrm{Ag}-\mathrm{Cu}-4.5 \mathrm{Ti} / \mathrm{h}-\mathrm{BN}$ interface (center), $\mathrm{h}-\mathrm{BN}$ region (right), illustrating $\mathrm{X}$-ray maps obtained by EDS of the following elements (b) Ti-K, (c) Cu-K and (d) Ag-L.

\section{CONCLUSION}

It was possible to identify the feasibility of using high vacuum brazing process to guarantee the formation of Kovar® / Ticusil® / h-BN brazed pair, considering the BPM design for Sirius project.

Proper selection of the filler metal alloy promotes the chemical reactions at the interface and it is related to the composition of the base materials. Thus, the use of $\mathrm{Ag}-\mathrm{Cu}-4.5 \mathrm{Ti}$ alloy ensures diffusion in a manner that occurs bonding reactions at the brazed interface.

The results showed the that despite the low surface wettability surface of $h-B N$ it was possible to produce a sound brazed metal-ceramic pair.

The surface wettability test of $\mathrm{h}-\mathrm{BN}$ with $\mathrm{Ag}-\mathrm{Cu}-4.5 \mathrm{Ti}$ showed low contact angle, which guarantees good wettability. From a practical point of view, this effect in the semi-liquid state reduces brazing temperature, which causes less residual stress due to the lower input of thermal energy in the system.

The brazed microstructure results corroborate the wettability tests of $h-B N$. Although the alloy is not completely melted at the working temperature, the liquid metal reacts with the ceramic substrate, presenting good spreading of the brazed filler. The visual analysis using microstructure imagens showed good appearance and the formation of h-BN / Ag-Cu-4.5Ti / Kovar® continuous bonded joint layer. 


\section{ACKNOWLEDGMENTS}

This work was supported by the Sao Paulo Research Foundation (FAPESP), grant \#2015/50110-2.

\section{REFERENCES}

1 Schwartz, M., M., Brazing Metals Park, OH, ASM International, 1990.

2 Nascimento, R. M. Uniões Al2O3/ Al2O3 e Fe-Ni-Co/ Al2O3 Produzidas por Brasagem com Metal Ativo. Florianópolis. 1997.

3 Bagnato, O. R., Estudo de Juntas Metal-Cerâmica Brasadas com Metal Ativo para Aplicações em Ultra-Alto Vácuo, Dissertação de Mestrado, Faculdade de Engenharia Mecânica, Unicamp, 1992.

4 Santos, R. G., Transformações de Fases em Materiais Metálicos, Ed. Unicamp,

5 p.149-191, 2005.

6 Sobczak, N. et al. The Mystery of Molten Metal. 69th World Foundry Congress (WFC), Hangzhou China, 2010.

7 Pereira, J. C. Estudo da Molhabilidade de Ligas de Adição à Base de Prata para Insertos Cerâmicos Para Aplicação em Brocas de Perfuração de Poços de Petróleo. Tese de Doutorado, PPGCEM-UFRN, 2012.

8 Sobczak, N. High-temperature Wettability Measurements in Metal/ceramic Systems Some Methodological Issues, Solid State and Materials Science 9, 241-253, 2005.

9 M.G. Nicholas, S.D. Peteves. Reactive Joining Chemical Effects on the Formation and Properties of Brazed and Diffusion Bonded Interfaces. Scripta Metallurgica et Materialia, Vol. 31, No. 8, pp. 1091-1096, 1994.

10 Y. Sechi, T. Matsumoto, K.o Nakata. Time Dependence of Contact Angles Between Silver Copper Titanium Alloys and Boron Nitride. Characterization and Control of Interfaces for High Quality Advanced Materials III, 175-182, 2010.

11 Lugscheider, E., Tillamnn, W. Methods for Brazing Ceramic and Metal/Ceramic Joints. Materials \& Manufacturing Processes, Vol. 8, pp 219-238, 1993.

12 Travessa, D. N. Ferrante, M. Junção por Difusão em Estado Sólido de Al2O3/Aço

13 Naidich, Y.V. et. al. Liquid Metal Wettability and Advanced Ceramic Brazing. Journal of the European Ceramic Society 28, 717-728, 2008.

14 Xiangdong, M. Xinyang, W. Li, S. J. Wei. A Research on Interfacial Reaction of Brazing Joint of Alumina Ceramics to Metals. Materials Science Forum Vols. 654-656, pp 27322734, Switzerland, 2010.

15 Fujii, $H$. Nakae $H$. and Okada, K. Interfacial Reaction Wetting in the Boron Nitride/molten Aluminum System", Acta Metall, mater., 41, $2963-71$ (1993).

16 Steinborn, C. et al. Correlation between microstructure and electrical resistivity of hexagonal boron nitride ceramics. Journal of the European Ceramic Society 33, 12251235, 2013.

17 Eichler, J. Lesniak. C. Boron nitride (BN) and BN composites for high-temperature applications. Journal of the European Ceramic Society, 2008.

18 Z. W. Yang, L. X. Zhang, X. Y. Tian, Q. Xue, J. C. Feng - Interfacial microstructure and mechanical property of SiO2-BN ceramics and Invar joint brazed with $\mathrm{Ag}-\mathrm{Cu}-\mathrm{Ti}$ active filler metal - Materials Science and Engineering A 534 (2012) p. 309-313. 